\section{Promethazine in the treatment of postoperative nausea and vomiting: a systematic review}

\author{
JOSKO MARKIC • ANNA LOUISE RIDGE
}

JOSKO MARKIC ( $\triangle)$

University Hospital of Split

Department of Pediatrics

Pediatric Intensive Care Unit Spinciceva 1, 21000 Split, Croatia Phone: + 385-21-556-686

Fax: +385-21-556-729

E-mail: jmarkic@kbsplit.hr

ANNA LOUISE RIDGE Balfour Hospital New Scapa Road, Kirkwall Orkney KW15 1BH United Kingdom

\begin{abstract}
Postoperative nausea and vomiting (PONV) is among the most important concerns of patients undergoing surgery. The incidence ranges from $30 \%$ to $70 \%$. The incidence of PONV correlates with a number of risk factors a patient possesses. Patient-related risk factors in adults are: female gender, history of PONV, duration of surgery $>60$ min, nonsmoking status, history of motion sickness, and postoperative use of opioids. Risk factors in children are: duration of surgery $\geq 30$ minutes, age $\geq 3$ years, strabismus surgery, and a history of PONV in the patient, parent or sibling. Treatment of PONV includes various classes of medications and none of them is entirely effective. If it is necessary to use combination therapy, then medicines with different sites of activity should be used. Promethazine is a phenothiazine derivate available as a medicine since its introduction in 1946. In this article, a search was performed to identify all published papers and reports evaluating the effectiveness of promethazine for the management of postoperative nausea and vomiting in adults and children. The results of this review support the finding that promethazine is not recommended as a first-line agent in the treatment of PONV, but can be considered for use as a rescue antiemetic.
\end{abstract}

Key words: promethazine, postoperative nausea and vomiting, treatment

\section{Introduction}

Postoperative nausea and vomiting (PONV), together with pain, is among the most important concerns of patients undergoing surgery. Nausea, vomiting and retching can occur with all types of anesthesia (general, regional or local). (1) The incidence ranges from $30 \%$ to $50 \%$, with numbers reported as high as $70 \%$ in higher-risk patients. (2) Consequences of PONV are numerous and include rupture of stitches, bleeding, electrolyte imbalances, dehydration, and aspiration of gastric contents. (3, 4) Patients who experience PONV also require additional health care. All of this may delay discharge from the postanesthesia care unit (PACU) or require additional medical interventions, resulting in increased health care costs.
This article will review the therapeutic efficacy of promethazine in the treatment of postoperative nausea and vomiting.

\section{Evaluation and management of PONV}

Current strategies for the prevention of PONV include: (a) proactive risk assessment, (b) avoiding PONV "triggers", and (c) administration of prophylactic antiemetic medications. (1)

Apfel et al. created a risk assessment scoring system and included four patient-related risk factors in it: female gender, nonsmoking status, history of PONV or motion sickness, and postoperative use of opioids. (5) Koivuranta et al. created a similar scoring system, but with five factors: female gender, history of PONV, duration of surgery $>$ $60 \mathrm{~min}$, nonsmoking status, and history of motion sickness. (6) The incidence of
PONV correlates with the number of risk factors a patient possesses. A pediatric scoring system has been designed by Eberhart et al. (7) Risk factors associated with increased frequency of PONV in children are: duration of surgery $\geq$ 30 minutes, age $\geq 3$ years, strabismus surgery, and a history of PONV in the patient, parent or sibling.

Consensus panel guidelines, developed under the auspices of the Society of Ambulatory Anesthesia, recommended the prophylactic use of antiemetic therapy only for patients who are at moderate to high risk for developing PONV.

A modified and simplified treatment algorithm for the management of PONV is shown in figure 1.

As shown in figure 1, treatment of PONV includes various classes of medications. None of the available antiemetics is entirely effective. If it is necessary to 


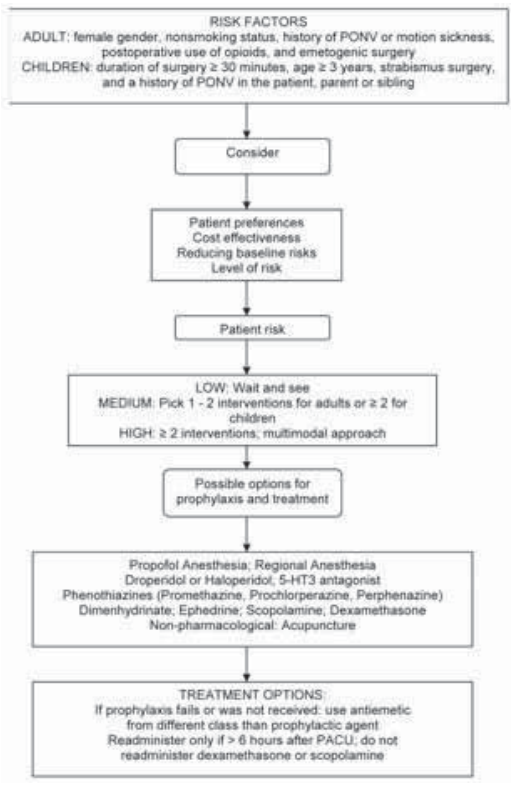

Figure 1. Treatment algorithm modified from Gan et al. (8)

use combination therapy, then medicines with different sites of activity should be used to optimize efficacy. (8) All prophylaxis in children at moderate or high risk for postoperative vomiting should include combination therapy using a serotonin (5-HT3) antagonist and a second medicine. (8)

Promethazine offers the advantage of low cost, slow-intramuscular absorption, and a long elimination half-life (9), making it potentially attractive for use in outpatient surgery. $(9,10)$

\section{Promethazine in treatment of PONV}

Promethazine is a phenothiazine derivate available as a medicine since its introduction in 1946. It acts as a histamine $\mathrm{H} 1$-receptor antagonist with moderate muscarinic and dopamine (D2) receptor blocking activities. (11) Promethazine is available worldwide, in some countries as over the counter medicine, and in some only by prescription. It is available in the form of an injection, oral liquid and tablet. Indications for use are: treatment of allergies, adjunct to anesthesia, motion sickness, nausea and vomiting from any cause, adjunct to management of post-opera- tive pain, general sedation, and obstetric sedation. It is contraindicated in patients with known hypersensitivity to promethazine (cross reactivity with other phenothiazines may also occur), in patients with severe toxic central nervous system (CNS) depression or coma, and in children $<2$ years of age. (12) Promethazine should be used with extreme caution in children, due to the potentially severe risk of respiratory depression. Sudden deaths in children have been associated with excessively high doses of promethazine. Therefore, the lowest effective doses are recommended in children and concomitant use of other medications having respiratory depressant effects should be avoided.

Promethazine should not be given subcutaneously or intra-arterially due to severe local reactions including necrosis. Intravenous (I.V.) administration may also cause serious tissue reactions and it should be used only in emergency situations or when intramuscular or oral administration is contraindicated. Veins should be large and patent. Promethazine should be used with caution in patients with cardiovascular disease, narrow-angle glaucoma, prostatic hypertrophy, bone marrow depression, impaired liver function, asthma, peptic ulcer disease, sleep apnea, and hypertensive crisis. Promethazine may lower the seizure threshold so it should be used with caution in patients with seizure disorders or if they are receiving other medications which may also lower the seizure threshold. Adverse effects of promethazine are numerous and they include cardiovascular symptoms (tachycardia, bradycardia, hypotension, hypertension), CNS symptoms (sedation, excitation, extrapyramidal reactions, dystonia, neuroleptic malignant syndrome, hallucinations, insomnia), dermatologic symptoms (photosensitivity, rash), gastrointestinal symptoms (xerostomia, abdominal pain, diarrhea), hematologic symptoms (thrombocytopenia, agranulocytosis), and other such as cholestatic jaundice, hepatitis, thrombophlebitis, blurred vision, and tinnitus. (12)
When administered for the treatment of nausea and vomiting, promethazine dosage regimen in adults should be 25 mg orally at night, increased to 50-75 $\mathrm{mg}$ at night or $25 \mathrm{mg} 2-3$ times daily if necessary (maximum, $100 \mathrm{mg}$ in 24 hours), or by deep intramuscular injection or by slow intravenous injection 12.5-25 mg, repeated at intervals of not less than 4 hours (usual maximum, 100 mg in 24 hours). (13)

\section{The review of promethazine effectiveness in treatment of PONV}

Medline, Cochrane Database of Systematic Reviews, and Cochrane Central Register of Controlled Trials (1970 - June 2010) were searched to identify all published papers and reports evaluating the effectiveness of promethazine for the management of postoperative nausea and vomiting in adults and children. Search terms were promethazine, and postoperative nausea and vomiting . Studies in languages other than English were excluded. Titles and abstracts of retrieved papers were reviewed. Studies were included if they were systematic reviews or randomized controlled trials (RCTs). Non-randomized clinical trials were also included if the data published in them was considered relevant for this review. The reference lists of included studies were hand searched to identify any additional studies. The studies in which promethazine was used as part of a combination of medicines (for example, lytic cocktails) were excluded. Different medicines, doses, and regimens have been used in these studies and the findings cannot be used to conclude which agent is most effective for preventing PONV.

After analysis of retrieved papers, 19 relevant clinical trials and 4 systematic reviews were identified evaluating the effectiveness of promethazine for the management of PONV. Data relevant for evaluation of promethazine effectiveness was extracted and tabulated (table 1, table 2).

The majority of 19 clinical trials (12/19; $63,2 \%$ ) were double-blind RCTs, 3 were RCTs, and 4 articles presented nonran- 
Table 1. Clinical trials evaluating the effectiveness of promethazine for the management of PONV.

\begin{tabular}{|c|c|c|}
\hline No. & Article; Study Type; Study Design & Conclusion \\
\hline 01. & $\begin{array}{l}\text { Conner (1977) (14) } \\
\text { Double-blind RCT; Adults aged } 18 \text { - } 70 \text { years }(\mathrm{N}=270) \\
\text { One hour before surgery, patients received morphine } 5 \mathrm{mg} \text { or } \\
10 \mathrm{mg} \text { alone or in combination with promethazine } 6.25,12.5 \text {, } \\
\text { or } 25 \mathrm{mg} \text {. Promethazine } 25 \mathrm{mg} \text { alone also was studied. }\end{array}$ & $\begin{array}{l}\text { The use of promethazine had no effect on incidence of nau- } \\
\text { sea. Also, it was reported that there was no statistically signifi- } \\
\text { cant difference between the various doses of promethazine. }\end{array}$ \\
\hline 02. & $\begin{array}{l}\text { Dodson (1978) (15) } \\
\text { Double-blind RCT; Women aged } 16 \text { - } 70 \text { years }(\mathrm{N}=124) \\
\text { As a premedication, } 2-3 \text { hours before surgery: 1. Iorazepam } \\
2.5 \text { mg p.o.; 2. promethazine } 50 \text { mg p.o. }\end{array}$ & $\begin{array}{l}\text { Vomiting during anesthesia, or during the } 1^{\text {st }} \text { hour after surgery } \\
\text { occurred in } 8 \text { patients, of whom } 7 \text { received lorazepam. There } \\
\text { was no difference between the groups in respect to late PONV. }\end{array}$ \\
\hline 03. & $\begin{array}{l}\text { Vella (1985) (16) } \\
\text { Double-blind RCT; Women in labour ( } \mathrm{N}=477) \text {. } \\
\text { Patients received pethidine (100-150 mg) i.m. along with } \\
\text { either: } 1 \text {. isotonic saline ( } 2 \mathrm{ml} \text {, Control group); } 2 \text {. prometh- } \\
\text { azine } 25 \mathrm{mg} ; 3 . \text { metoclopramide } 10 \mathrm{mg}\end{array}$ & $\begin{array}{l}\text { Both metoclopramide and promethazine prevented the } \\
\text { increase in nausea and vomiting associated with pethidine } \\
\text { administration, with promethazine having a more sustained } \\
\text { effect - by } 4 \text { hours promethazine produced a significant reduc- } \\
\text { tion in nausea from the level before pethidine administration. }\end{array}$ \\
\hline 04. & $\begin{array}{l}\text { Blanc (1991) (10) } \\
\text { Double-blind RCT; Children aged } 2-10 \text { years }(\mathrm{N}=100 ; 47 \mathrm{M} \\
+53 \mathrm{~F} \text { ) } \\
\text { Patients received: } 1 . \text { droperidol } 0.075 \mathrm{mg} / \mathrm{kg} \text { i.v. + placebo } \\
\text { i.m.; 2. promethazine } 0.5 \mathrm{mg} / \mathrm{kg} \text { i.v. + promethazine } 0.5 \mathrm{mg} / \\
\mathrm{kg} \text { i.m. (max. } 25 \mathrm{mg} \text { ) }\end{array}$ & $\begin{array}{l}\text { The incidence of vomiting pre-discharge in groups } 1 \text { and } 2 \\
\text { was not significantly different. The incidence of vomiting post- } \\
\text { discharge and overall was significantly higher with droperidol } \\
\text { than with promethazine. } \\
\text { Promethazine pretreatment reduced the incidence of postop- } \\
\text { erative vomiting in unpremedicated children. }\end{array}$ \\
\hline 05. & $\begin{array}{l}\text { Silverman (1992) }(17) \\
\text { RCT; Women aged } 18-60 \text { years }(\mathrm{N}=30) \\
\text { In patient care unit, patients were assigned to } \\
\text { receive patient-controlled analgesia: } 1 . \text { morphine; } 2 \text {. } \\
\text { morphine + promethazine } 0,625 \text { mg with each morphine } \\
\text { dose (average of } 17,6 \text { mg over } 24-h \text { period) }\end{array}$ & $\begin{array}{l}\text { Visual analogue scale (VAS) scores for nausea were not sig- } \\
\text { nificantly different between the two groups. } \\
\text { The addition of promethazine to morphine was associated } \\
\text { with a significant decrease in the symptom-therapy score for } \\
\text { nausea. }\end{array}$ \\
\hline
\end{tabular}

Sandhya (1994) (18)

RCT; Women aged between $22.4 \pm 2.5$ and $25.0 \pm 4.88$ years $(\mathrm{N}=32)$

06. Patients received pentazocine $0.6 \mathrm{mg} / \mathrm{kg}$ i.v. 5 minutes before induction of anesthesia along with either: 1 . isotonic saline (Control group); 2. promethazine $0.5 \mathrm{mg} / \mathrm{kg}$; 3 . metoclopramide $0.2 \mathrm{mg} / \mathrm{kg}$

Tarkkila (1995) (19)

Double- blind RCT; Adults aged $50-83$ years $(N=60)$

For premedication the patients received: 1 . oral diazepam

07. $\quad 5-15 \mathrm{mg}+$ placebo patch; 2 . oral promethazine $10 \mathrm{mg}+$ placebo patch: 3 . oral promethazine $10 \mathrm{mg}+$ transdermal scopolamine patch $1.5 \mathrm{mg}$

Rodola (1995) (20)

Double- blind RCT; Adults aged $18-40$ years ( $N=120 ; 58 \mathrm{M}$

08. $+62 \mathrm{~F})$ Premedication before surgery: 1 . no treatment = Control group; 2. atropine $0,01 \mathrm{mg} / \mathrm{kg}$ i.m. + diazepam $0.2 \mathrm{mg} / \mathrm{kg}$ p.o.; 3. atropine $0,01 \mathrm{mg} / \mathrm{kg} \mathrm{i.m}$. + promethazine $1 \mathrm{mg} / \mathrm{kg} \mathrm{i.m}$.

Promethazine and metoclopramide in the doses used in this study are ineffective for antiemetic prophylaxis.

The combination of oral promethazine and transdermal scopolamine was most effective in reducing PONV and also reduced the need for postoperative pain treatment.

Khalil (1999) (21)

Double- blind RCT; Adults aged $13-72$ years $(\mathrm{N}=87 ; 46 \mathrm{M}$ $+41 \mathrm{~F})$.

09. At induction of anesthesia, patients received: 1 . ondansetron $4 \mathrm{mg}$; 2. promethazine $25 \mathrm{mg}$; 3 . promethazine $12.5 \mathrm{mg}+$ ondansetron $2 \mathrm{mg}$; 4 . placebo

The combination of promethazine and atropine was very effective in reducing occurrence of PONV.

Promethazine is suggested as an effective and inexpensive medication to prevent PONV in orthopedic surgery.

Over the 24-h period, the incidence of nausea was significantly reduced in promethazine and combination group compared with placebo group. Incidence of vomiting was significantly reduced in combination group compared with promethazine, ondansetron and placebo group.

Incidence of combined nausea and vomiting was reduced in promethazine and combination group compared with placebo group.

Combination of ondansetron and promethazine and promethazine alone are effective and inexpensive choices.

\section{Parlow (1999) (22)}

Double-blind RCT; Women aged $35 \pm 9$ years $(\mathrm{N}=95)$

10. Patients received droperidol $0.5 \mathrm{mg}$ i.v. intraoperatively, and prior to transfer from post-anesthetic recovery room: 1. promethazine $0.6 \mathrm{mg} / \mathrm{kg}$ i.m.; 2. placebo

The incidence of nausea, vomiting, and rescue antiemetic use in the recovery room was similar between the groups. Promethazine had no effect on postdischarge nausea scores, vomiting, or rescue antiemetic requirements. 
Kreisler (2000) (23)

Double-blind RCT; Adults aged between $46.7 \pm 15.7$ and 50.0

\pm 15.3 years $(\mathrm{N}=150 ; 59 \mathrm{M}+91 \mathrm{~F})$

11. Before emergence from general anesthesia, patients received

PONV prophylaxis: droperidol $0.625 \mathrm{mg}$ i.v. or placebo. If

PONV occurred in the postanesthesia care unit, patients received rescue antiemetic $(\mathrm{N}=31)$ : 1 . droperidol 0.625 i.v.; 2. ondansetron $4 \mathrm{mg}$ i.v.; 3. promethazine $12.5 \mathrm{mg}$ i.v. Ikechebelu (2003) (24)

12. Retrospective study; Women aged $18-40$ years $(\mathrm{N}=295)$ Premedication: 1 . atropine $0.6 \mathrm{mg}$; 2 . atropine $0.6 \mathrm{mg}+$ diazepam $10 \mathrm{mg}$; 3 . atropine $0.6 \mathrm{mg}$ + promethazine $50 \mathrm{mg}$ Chia (2004) (25)

Double-blind RCT; Women aged between $44.0 \pm 10.2$ and $47.0 \pm 5.2$ years $(N=90)$

1. Pre-group - received promethazine $0.1 \mathrm{mg} / \mathrm{kg}$ infusion before anesthesia induction

2. Post-group - received promethazine $0.1 \mathrm{mg} / \mathrm{kg}$ infusion at the end of surgery

3. Control group - received normal saline

Moser (2006) (26)

Prospective study (nonrandomized); Adults aged $27-81$

14. years $(\mathrm{N}=87)$

1. promethazine $6.25 \mathrm{mg}$ or $12.5 \mathrm{mg}$ i.v.; 2 ondansetron $4 \mathrm{mg}$ i.v.

\section{Habib (2005) (27)}

Retrospective review (not randomized); Adults aged 18-65 years $(N=431)$

Rescue antiemetic in PACU: 1. ondansetron $4 \mathrm{mg}$; 2 . droperi-

15. dol 0.625 to $1.25 \mathrm{mg}$; 3 . metoclopramide $10 \mathrm{mg}$; 4 . promethazine 6.25 to $25 \mathrm{mg} ; 5$. dimenhydrinate 25 to $50 \mathrm{mg}$.

In the original double-blind $\mathrm{RCT}$, patients $(\mathrm{N}=2061)$ received PONV prophylaxis before the induction of anesthesia: ondansetron $4 \mathrm{mg}$, droperidol 0.625 or $1.25 \mathrm{mg}$, or placebo. (28)

\section{Nale (2007) (29)}

Double-blind RCT; Adults aged $16-80$ years $(N=120)$.

Oral premedication 1 hour prior surgery and subsequent at 8

16. hour intervals for total 24 hours:

1. shaving of fresh ginger $250 \mathrm{mg} ; 2$. metoclopramide 10 mg; 3. prochlorperazine $5 \mathrm{mg}$; 4. promethazine $20 \mathrm{mg} ; 5$. ondansetron $4 \mathrm{mg}$; 6 . placebo

\section{Habib (2007) (30)}

Retrospective review (not randomized); Adults aged $>18$ years

17. Patients $(\mathrm{N}=18209)$ initially received PONV prophylaxis with ondansetron $4 \mathrm{mg}$. Rescue antiemetic administered in PACU within 4 hours after PONV prophylaxis $(\mathrm{N}=3814)$ : 1 . ondansetron $4 \mathrm{mg}$; 2 . promethazine 6,$25 ; 12,5$ or $25 \mathrm{mg}$

\section{Pellegrini (2009) (31)}

RCT; Adults aged between $33.98 \pm 10.9$ and $37.09 \pm 11.0$ years $(\mathrm{N}=85)$

18. Patients received PONV prophylaxis with ondansetron $4 \mathrm{mg}$ Rescue (PONV) treatment with: 1 . inhaled $70 \%$ isopropyl alcohol (IPA); 2. promethazine 12,5 to $25 \mathrm{mg}$ i.v.

Gan (2009) (32)

Double-blind RCT; Women aged between $32.8 \pm 7.2$ and 34.3 \pm 8.3 years $(N=138)$

19. $15 \mathrm{~min}$ before the end of surgery i.v. and than $12 \mathrm{~h}$ after surgery for five oral doses, patients received:

1. granisetron $0.1 \mathrm{mg}$ i.v. (1 mg oral) ; 2. promethazine 6.25 mg i.v. (12.5 mg oral); 3 . granisetron + promethazine (combination, same doses as above)
Significantly more people in placebo group experienced PONV than in droperidol prophylaxis group. Because of the small sample size, the authors were unable to show statistically significant difference in efficacy among different medicines.

Promethazine significantly reduced nausea and vomiting. Premedication with promethazine is advocated for better recovery outcome.

There were significant differences regarding nausea, vomiting, and patients who asked for antiemetic at the first 0-6 h and $0-24 \mathrm{~h}$ after surgery between group 3 and groups 1 and 2. Administration of promethazine pre- or post- operatively reduced PONV and the number of patients asking for rescue antiemetic on postoperative day 1 , as compared with Control group.

There were no significant differences between the groups concerning relieve of nausea and vomiting at 1 and 3 hours. In patients requiring treatment for nausea and/or vomiting from any cause except chemotherapy or pregnancy, promethazine was as effective as ondansetron.

In patients who failed prophylaxis with ondansetron, the complete response rate (no nausea, no emesis, no need for further rescue) after rescue with promethazine was significantly higher compared with a second dose of ondansetron. In patients who failed prophylaxis with droperidol, the complete response rate was significantly higher after rescue with promethazine and dimenhydrinate compared with a second dose of droperidol. An antiemetic acting at a receptor different from the site of action of the medicine used for PONV prophylaxis should be considered for the treatment of established PONV.

The frequency and quantity of PONV was significantly lower in the ginger group than in the control group.

The incidence of nausea was considerably less with promethazine than in the control group.

In patients with established PONV who failed ondansetron prophylaxis and needed rescue antiemetic treatment, the response rate (no nausea, no emesis, no need for further rescue) was significantly higher after promethazine than after repeat dose of ondansetron.

There was no difference in efficacy between $6.25 \mathrm{mg}$ and higher doses of promethazine for the treatment of established PONV in those patients

IPA is as effective in treating PONV as promethazine in patients who have been identified as high risk for PONV.

Patients in the combination group had a significantly higher cumulative total response rate (no vomiting/retching, no more than mild nausea, no use of rescue antiemetic) compared with promethazine group. The maximum nausea scores were significantly lower in the combination group than in the promethazine group. There was no difference between groups in satisfaction with PONV management.

Combination of granisetron and promethazine is more effective in reducing PONV and PDNV than promethazine monotherapy.

F, females; M, males; N, number; PACU, post-anesthesia care unit; PONV, postoperative nausea and vomiting; RCT, randomized controlled trials. 
Table 2. Systematic reviews evaluating the effectiveness of promethazine for the management of postoperative nausea and vomiting.

\begin{tabular}{|c|c|c|c|}
\hline No. & Article; Methodology & $\begin{array}{l}\text { Remarks / Results concerning pro- } \\
\text { methazine role }\end{array}$ & Conclusions; Comment \\
\hline 01. & $\begin{array}{l}\text { Tramer (1999) (33) } \\
\text { MEDLINE (1966 - Apr 1998), EMBASE } \\
\text { (1980 - Apr 1998), and Cochrane library } \\
\text { search was conducted. Included one } \\
\text { study with promethazine (17) }\end{array}$ & $\begin{array}{l}\text { The addition of promethazine to mor- } \\
\text { phine was associated with a significant } \\
\text { decrease in the symptom-therapy score } \\
\text { for nausea. }\end{array}$ & $\begin{array}{l}\text { Promethazine showed promising results } \\
\text { but the number of patients is limited and } \\
\text { the recommendations cannot be based } \\
\text { on the available evidences. }\end{array}$ \\
\hline 02. & $\begin{array}{l}\text { Fujii (2005) (34) } \\
\text { MEDLINE and EMBASE search (Jan } \\
1990 \text { - Oct 2003) was conducted. } \\
\text { Included two studies with promethazine } \\
\text { (21), (22) }\end{array}$ & $\begin{array}{l}\text { Over the 24-h period, the incidence } \\
\text { of PONV was significantly reduced in } \\
\text { promethazine group and combination } \\
\text { group of promethazine and ondanse- } \\
\text { tron compared with placebo group and } \\
\text { ondansetron group. (21) } \\
\text { There was no difference between the } \\
\text { placebo and promethazine groups in } \\
\text { the worst level of nausea reported, the } \\
\text { incidence of nausea of any severity, } \\
\text { moderate to severe nausea, vomiting, or } \\
\text { the need for rescue antiemetics follow- } \\
\text { ing discharge. (22) }\end{array}$ & $\begin{array}{l}\text { Among traditional antiemetics (e.g., } \\
\text { anticholinergics, antihistamines, phe- } \\
\text { nothiazines, butyrophenones, and } \\
\text { benzamide), dimenhydrinate and } \\
\text { perphenazine are highly efficacious for } \\
\text { prophylaxis against PONV following lap- } \\
\text { aroscopic cholecystectomy. }\end{array}$ \\
\hline 03. & $\begin{array}{l}\text { Carlisle (2006) (35) } \\
\text { Cochrane systematic review } \\
\text { The Cochrane Central Register of Con- } \\
\text { trolled Trials (Jan } 1966 \text { - May 2004), } \\
\text { EMBASE (Jan } 1985 \text { - May 2004), } \\
\text { CINAHL (1982 - May 2004), ISI WOS (to } \\
\text { May 2004), Lilac, and Ingenta searches } \\
\text { were conducted. } \\
\text { Included } 7 \text { clinical trials from Table } 1 \\
\text { evaluating the effectiveness of promet- } \\
\text { hazine: (21), (22), (10), (19), (15), (20), } \\
\text { (18) }\end{array}$ & $\begin{array}{l}\text { Compared to placebo, the risk for PONV } \\
\text { is decreased by promethazine, but } \\
\text { there was no evidence that the risk of } \\
\text { postoperative vomiting is changed by } \\
\text { promethazine. } \\
\text { Compared to no treatment, there was no } \\
\text { evidence that promethazine changes the } \\
\text { risk of postoperative nausea, or the risk } \\
\text { of postoperative vomiting. }\end{array}$ & $\begin{array}{l}\text { Eight medicines (droperidol, metoc- } \\
\text { lopramide, ondansetron, tropisetron, } \\
\text { dolasetron, dexamethasone, cyclizine } \\
\text { and granisetron) were identified that reli- } \\
\text { ably prevented nausea or vomiting after } \\
\text { surgery. } \\
\text { There was no reliable evidence that one } \\
\text { medicine was better than another. }\end{array}$ \\
\hline 04. & $\begin{array}{l}\text { Fujii (2008) (36) } \\
\text { MEDLINE and EMBASE searches from } \\
\text { Jan } 1990 \text { to Dec } 2007 \text { were conducted. } \\
\text { Included one study with promethazine } \\
\text { (21) }\end{array}$ & $\begin{array}{l}\text { Over the 24-h period, the incidence } \\
\text { of PONV was significantly reduced in } \\
\text { promethazine group and combination } \\
\text { group of promethazine and ondansetron } \\
\text { compared with placebo group. } \\
\text { There was no difference between pla- } \\
\text { cebo and ondansetron groups. }\end{array}$ & $\begin{array}{l}\text { Combination of antiemetic therapy } \\
\text { with an antiserotonin (ondansetron, } \\
\text { granisetron) plus traditional antiemetics } \\
\text { (promethazine, droperidol) or dexam- } \\
\text { ethasone is highly effective for the pro- } \\
\text { phylaxis against PONV. }\end{array}$ \\
\hline
\end{tabular}

PONV, postoperative nausea and vomiting.

domized prospective or retrospective studies. The quality of data collection was operator-dependent and in some aspects, like the evaluation of severity of nausea, may be inaccurate or underreported. Objective evaluation of severity of nausea is very difficult and "there may be as many scales for assessing nausea/vomiting as there are investigative groups studying the phenomenon". (37) Four clinical trials used validated visual analogue (VAS) or verbal rating (VRS) scales to assess nausea with " 0 " representing no nausea and "10" representing worst possible nausea, in seven clinical trials the seve- rity was not assessed or it was unclear how the assessment was done, and the other eight reported using a scoring system which was not validated, and was not reported again in other articles. Additional limitations are the low or limited number of patients available for analysis, the recruitment of only women, and the non-existence of placebo groups in some studies. The limitation of some nonrandomized studies was the choice of antiemetic medicines, which was left to the discretion of the attending anesthesiologist. However, those clinical trials evaluated the effectiveness of pro- methazine in 6486 patients of which 6299 were adults aged 16 or more, and 100 were children. One clinical trial included 87 patients aged $13-72$ years, but we were unable to identify the exact number of participants that were under or over 16 years from the published data. (21) Promethazine was used in different dosages and administered using different routes of administration (oral, intramuscular, intravenous, combined intramuscular + intravenous) across the studies. The use of different dosages may have led to different effects. The doses of promethazine were determined in 
three ways:in 12 studies, the dose of promethazine was fixed and ranged from $6,25 \mathrm{mg}$ to $50 \mathrm{mg}$; in 5 studies, the dose of promethazine was calculated according to the patient's body weight (each of these studies used different dosing regimes, with doses ranging from $0,1 \mathrm{mg} / \mathrm{kg}$ to $1 \mathrm{mg} / \mathrm{kg}$ ) and in one study, promethazine was added to morphine as part of a patient-controlled analgesia regimen and the patient was administered on average $17,6 \mathrm{mg}$ of promethazine over a 24-h period.

Due to the heterogeneity of the retrieved clinical trials, it was not possible to pool the data in a meta-analysis as no common or unique outcome could be determined. In order to analyze the effect of promethazine as precisely as possible, the outcomes of retrieved clinical trials presented in Table 1 are reported by the intervention used. Six different groups were identified:

1) Promethazine vs. placebo In seven clinical trials (16, 18, 20-22, 24, 25), promethazine was compared to placebo. In 5 of them women only participated ( $N=989$; aged $18-55$ years), one trial was with adults $(N=120)$ aged 18 - 40 years, and one trial included 87 patients aged 13 - 72 years. Promethazine was found effective in reducing the occurrence of PONV in 5 articles, while 2 studies found it ineffective for antiemetic prophylaxis.

2) Promethazine vs. another antiemetic medicine

In three clinical trials $(13,26,29)$, promethazine was compared to another antiemetic medicine. One study with children $(N=100)$, aged $2-10$ years, reported that promethazine reduced the incidence of postoperative vomiting when compared to droperidol, and the other with adults ( $\mathrm{N}=87$ ) aged $27-81$ years, found promethazine as effective as ondansetron. The third study, with patients aged $16-80$ years $(\mathrm{N}=$ 120), found that shavings of fresh ginger decreased the incidence of PONV significantly when compared to placebo. The same study also evaluated the effect of promethazine and found that the incidence of nausea was conside- rably less with promethazine than in the control group.

3) Promethazine + another antiemetic vs. placebo or the same antiemetic alone

In three clinical trials $(19,21,32)$, combination of promethazine with another antiemetic was compared to placebo or to those same antiemetics administered alone. The study with 87 patients, aged 13 - 72 years, reported that a combination of promethazine with ondansetron reduced the incidence of nausea, vomiting and combination of nausea and vomiting when compared with placebo. The same study also reported the combination of promethazine and ondansetron to be more effective in reducing the incidence of vomiting and combined nausea and vomiting than promethazine or ondansetron alone. The second study with women ( $N=138$ ), aged $32.8 \pm 7.2$ and $34.3 \pm 8.3$ years, reported the combination of granisetron and promethazine to be more effective in reducing PONV than promethazine monotherapy. The third study, with adults $(\mathrm{N}=60)$ aged 50 - 83 years, also reported a combination of medicines to be the most effective. In this study, oral promethazine was combined with a transdermal scopolamine patch, and it was found that this combination is more effective in reducing incidence of PONV than promethazine monotherapy.

4) Promethazine in combination with morphine

In two clinical trials $(14,17)$, the effect of promethazine and morphine combination on incidence of nausea was tested. Both studies, one with adults ( $N=270)$ aged $18-70$ years and the other with women $(\mathrm{N}=30)$ aged 18 - 60 years found that the use of promethazine had no effect on the incidence of nausea. However, the later study reported that the use of promethazine, as an adjunct to morphine, was associated with a decrease in the symptom-therapy score for nausea.

5) Promethazine as a rescue antiemetic $\left(2^{\text {nd }}\right.$ line treatment) vs. other antiemetics In four clinical trials $(23,27,30,31)$, promethazine was used as a rescue antiemetic and was compared to other antiemetics. Adults $(\mathrm{N}=4361)$ participated in these trials. In two studies ( $N$ $=116)$ the difference between promethazine and other used medicine was not revealed. Other two studies ( $N=$ 4245) found promethazine to be more efficient in reducing PONV then the repeated dose of the same antiemetic used for prophylaxis.

6) Promethazine vs. Iorazepam

One clinical trial (15), with women (N $=124$ ) aged $16-70$ years, compared promethazine to the sedative lorazepam. The primary outcome of this trial was their effect as premedicants. However, no difference among them was found in respect to late PONV.

Four systematic reviews published between 1999 and 2008 were identified. Two systematic reviews $(33,36)$ included only one clinical trial evaluating the efficacy of promethazine in management of PONV. In one of them, it is stated that promethazine showed promising results in preventing nausea but due to limited number of patients a conclusion could not be made. The second review recommended a combination of an antiserotonin plus traditional antiemetics (this included promethazine) as highly effective for prophylaxis against PONV. The third review (34) included two clinical trials with promethazine. Among the conclusions in this review promethazine was not explicitly stated. The review which included the most clinical trials evaluating the effectiveness of promethazine was a Cochrane systematic review. (35) The objective of that review was to assess the prevention of postoperative nausea and vomiting by different medicines and to compare their efficacies. In order to achieve that, 737 randomized controlled trials involving 103237 people that compared a medicine with placebo or another medicine were included. Out of that, 7 clinical trials involving 618 people evaluated the effectiveness of promethazine. It was found that eight medicines reliably prevented nausea or vomiting after surgery: droperidol, metoclopramide, ondansetron, tropisetron, dolasetron, dexamethasone, 
cyclizine and granisetron. Those medicines prevented nausea or vomiting in three or four people out of every 10 who would have vomited or felt nauseated with a placebo. The authors did not find reliable evidence that one medicine was better than another. Side effects were mild. In regard to promethazine, there was no evidence that the risk of postoperative vomiting was affected by promethazine. Also, compared to no treatment, there was no evidence that promethazine changed the risk of postoperative nausea or the risk of postoperative vomiting.

\section{Conclusions}

It is evident from tables 1 and 2 that despite its widespread use, little data evaluating the therapeutic efficacy of promethazine is available. There are more articles evaluating efficacy of other antiemetics, but evaluation of these treatments was beyond the scope of this review.

Current guidelines do not recommend the use of promethazine and metoclopramide in the treatment of PONV, nor as a part of pharmagologic combination for adults and children, nor as a single agent in children. (8) A recent Cochrane Database Systematic Review found that, compared to placebo, the risk for PONV is decreased by promethazine, but there was no evidence that the risk of postoperative vomiting is changed by promethazine. Also, compared to no treatment, there was no evidence that promethazine changes the risk of postoperative vomiting and postoperative nausea.(35) The results of this review support the finding that promethazine is not recommended as a first-line medicine in the treatment of PONV, but can be considered for use as a rescue antiemetic.

\section{ACKNOWLEDGMENT}

Dr Anna Louise Ridge is a former staff member of the World Health Organization. The authors alone are responsible for the views expressed in this publication and they do not necessarily represent the decisions or policies of the World Health Organization.

\section{REFERENCES}

1. Skledar S, Williams B, Vallejo M, Dalby PL, Waters JH, Glick R, et al. Eliminating postoperative nausea and vomiting in outpatient surgery with multimodal strategies including low doses of nonsedating, off-patent antiemetics: is "zero tolerance" achievable? ScientificWorldJournal 2007;7:959-77.

2. Gan T. Postoperative nausea and vomiting--can it be eliminated? JAMA 2002;287(10):1233-6.

3. Gan T. Risk factors for postoperative nausea and vomiting. Anesth Analg 2006;102(6):1884-98.

4. Golembiewski J, Chernin E, Chopra T. Prevention and treatment of postoperative nausea and vomiting. Am J Health Syst Pharm 2005;62(12):1247-60

5. Apfel C, Läärä E, Koivuranta M, Greim CA, Roewer N. A simplified risk score for predicting postoperative nausea and vomiting: conclusions from cross-validations between two centers. Anesthesiology 1999;91(3):693-700.

6. Koivuranta M, Läärä E, Sníre L, Alahuhta S. A survey of postoperative nausea and vomiting. Anaesthesia 1997;52(5):443-9.

7. Eberhart L, Geldner G, Kranke P, Morin AM, Schauffelen A, Treiber H, et al. The development and validation of a risk score to predict the probability of postoperative vomiting in pediatric patients. Anesth Analg 2004;99(6):1630-7.

8. Gan T, Meyer T, Apfel C, Chung F, Davis PJ, Habib AS, et al. Society for Ambulatory Anesthesia guidelines for the management of postoperative nausea and vomiting. Anesth Analg 2007;105(6):1615-28.

9. Peroutka S, Snyder S. Antiemetics: neurotransmitter receptor binding predicts therapeutic actions. Lancet 1982;1 (8273):658-9.

10. Blanc V, Ruest P, Milot J, Jacob JL, Tang A. Antiemetic prophylaxis with promethazine or droperidol in paediatric outpatient strabismus surgery. Can J Anaesth 1991;38(1):54-60.

11. Sharma A, Hamelin B. Classic histamine H1 receptor antagonists: a critical review of their metabolic and pharmacokinetic fate from a bird's eye view. Curr Drug Metab 2003;4(2):105-29.

12. Taketomo CK, Hodding JH, Kraus DM, editors. Pediatric Dosage Handbook with International Trade Names Index. 14th ed. Hudson, Ohio: Lexi-Comp, Inc.; 2007.

13. Stuart MC, Kouimtzi M, Hill SR, editors. WHO model formulary 2008. Geneva: World Health Organisation; 2009.

14. Conner J, Bellville J, Wender R, Wapner S, Dorey FJ, Katz RL. Morphine and promethazine as intravenous premedicants. Anesth Analg 1977;56(6):801-7. 
15. Dodson M, Eastley R. Comparative study of two long-acting tranquillizers for oral premedication. Br J Anaesth 1978;50(10):1059-64.

16. Vella L, Francis D, Houlton P, Reynolds F. Comparison of the antiemetics metoclopramide and promethazine in labour. Br Med J (Clin Res Ed) 1985;290(6476):1173-5.

17. Silverman D, Freilich J, Sevarino F, Paige D, Preble L, O'Connor TZ. Influence of promethazine on symptom-therapy scores for nausea during patient-controlled analgesia with morphine. Anesth Analg 1992;74(5):735-8.

18. Sandhya, Yaddanapudi L. Evaluation of two antiemetic agents during outpatient gynaecological surgery. Singapore Med J 1994;35(3):271-3.

19. Tarkkila P, Törn K, Tuominen M, Lindgren L. Premedication with promethazine and transdermal scopolamine reduces the incidence of nausea and vomiting after intrathecal morphine. Acta Anaesthesiol Scand 1995;39(7):983-6.

20. Rodolí F, Cannelli G, Barbi S, Forte E, Anastasio C, Vagnoni S. Cost effective prophylaxys of postoperative nausea and vomiting by anesthetic premedication. Riv Eur Sci Med Farmacol 1995;17(6):243-6.

21. Khalil S, Philbrook L, Rabb M, Wells L, Aves T, Villanueva G, et al. Ondansetron/promethazine combination or promethazine alone reduces nausea and vomiting after middle ear surgery. J Clin Anesth 1999;11(7):596-600.

22. Parlow J, Meikle A, van Vlymen J, Avery N. Post discharge nausea and vomiting after ambulatory laparoscopy is not reduced by promethazine prophylaxis. Can J Anaesth 1999;46(8):719-24.

23. Kreisler N, Spiekermann B, Ascari C, Rhyne HA, Kloth RL, Sullivan LM, et al. Small-dose droperidol effectively reduces nausea in a general surgical adult patient population. Anesth Analg 2000;91(5):1256-61.

24. Ikechebelu J, Udigwe G, Obi R, Joe-Ikechebelu NN, Okoye IC. The use of simple ketamine anaesthesia for day-case diagnostic laparoscopy. J Obstet Gynaecol 2003;23(6):650-2.

25. Chia Y, Lo Y, Liu K, Tan PH, Chung NC, Ko NH. The effect of promethazine on postoperative pain: a comparison of preoperative, postoperative, and placebo administration in patients following total abdominal hysterectomy. Acta Anaesthesiol Scand 2004;48(5):625-30.

26. Moser J, Caldwell J, Rhule F. No more than necessary: safety and efficacy of lowdose promethazine. Ann Pharmacother 2006;40(1):45-8.

27. Habib A, Gan T. The effectiveness of rescue antiemetics after failure of prophylaxis with ondansetron or droperidol: a preliminary report. J Clin Anesth 2005;17(1):62-5.

28. Fortney J, Gan T, Graczyk S, Wetchler B, Melson T, Khalil S, et al. A comparison of the efficacy, safety, and patient satisfaction of ondansetron versus droperidol as antiemetics for elective outpatient surgical procedures. S3A-409 and S3A-410 Study Groups. Anesth Analg 1998;86(4):731-8.

29. Nale R, Bhave S, Divekar D. A Comparative Study of Ginger and Other Routinely Used Antiemetics for Prevention of Post Operative Nausea and Vomiting. J Anaesthesiol Clin Pharmacol 2007;23(4):405-10.

30. Habib A, Reuveni J, Taguchi A, White WD. A comparison of ondansetron with promethazine for treating postoperative nausea and vomiting in patients who received prophylaxis with ondansetron: a retrospective database analysis. Anesth Analg 2007;104(3):548-51.

31. Pellegrini J, DeLoge J, Bennett J, Kelly J. Comparison of inhalation of isopropyl alcohol vs promethazine in the treatment of postoperative nausea and vomiting (PONV) in patients identified as at high risk for developing PONV. AANA J 2009;77(4):293-9.

32. Gan T, Candiotti K, Klein S, Rodriguez Y, Nielsen KC, White WD, et al. Doubleblind comparison of granisetron, promethazine, or a combination of both for the prevention of postoperative nausea and vomiting in females undergoing outpatient laparoscopies. Can $\mathrm{J}$ Anaesth 2009;56(11):829-36.

33. Tramer M, Walder B. Efficacy and adverse effects of prophylactic antiemetics during patient-controlled analgesia therapy: a quantitative systematic review. Anesth Analg 1999;88(6):1354-61.

34. Fujii Y. The utility of antiemetics in the prevention and treatment of postoperative nausea and vomiting in patients scheduled for laparoscopic cholecystectomy. Curr Pharm Des 2005;11(24):3173-83

35. Carlisle J, Stevenson C. Drugs for preventing postoperative nausea and vomiting. Cochrane Database Syst Rev 2006;3:CD004125.

36. Fujii Y. Clinical strategies for preventing postoperative nausea and vomitting after middle ear surgery in adult patients. Curr Drug Saf 2008;3(3):230-9.

37. Morrow G. Methodology in behavioral and psychosocial cancer research. The assessment of nausea and vomiting. Past problems, current issues and suggestions for future research. Cancer 1984;53(10 Suppl):2267-80. 